\begin{abstract}
*Doutora em Direito pela Universidade de São Paulo (USP). Mestre em Direito pela Universidade de Marília (UNIMAR). Especialista em Direito Civil pela Associação Educacional Toledo de Ensino (ITE). Graduada em Direito pela Associação Educacional Toledo de Ensino (ITE). Email: danielapaiano@hotmail.com
\end{abstract}

\footnotetext{
**Doutora em Direito Civil pela Universidade de São Paulo (USP). Mestre em Direito Negocial pela Universidade Estadual de Londrina (UEL). Especialista em Metodologia do Ensino Superior pela Universidade Norte do Paraná (UNOPAR). Graduada em Direito pela Univerisdade Estadual de Londrina (UEL). Email: alessandracfurlan@uenp.edu.br
}

\section{ASPECTOS POLÊMICOS DO CONTRATO DE TRANSPORTE AÉREO DE PASSAGEIROS E BAGAGENS ${ }^{1}$}

\author{
CONTROVERSIAL ASPECTS IN PASSENGER AND LUGGAGE AIR \\ TRANSPORTATION CONTRACTS
}

\section{Daniela Braga Paiano* Alessandra Cristina Furlan**}

Como citar: PAIANO, Daniela Braga. FURLAN, Alessandra Cristina. Aspectos polêmicos do contrato de transporte aéreo de passageiros e bagagens Scientia Iuris, Londrina, v. 24, n. 3, p. 119-142, nov. 2020. DOI: $10.5433 / 2178-8189.2020 \mathrm{v} 24 \mathrm{n} 3 \mathrm{p} 119$. ISSN: $2178-8189$.

Resumo: O tema do presente artigo é o contrato de transporte de pessoas e bagagens, realizado por via aérea. Observa-se, sobre a modalidade, uma multiplicidade de fontes legislativas, com contradições e antinomias, particularmente, no tocante à indenização por danos materiais e morais. Identificar a legislação aplicada ao caso concreto exige esforço exegético do profissional do direito. Assim, o artigo objetiva um estudo, destacando os divergentes posicionamentos doutrinários e as principais soluções adotadas pelos tribunais pátrios. Apesar do tema não ser recente, a expansão do emprego de transporte aéreo por usuários das mais variadas classes sociais impõe a constante reflexão da regulamentação, de forma a consolidar soluções justas, tanto para os consumidores como para os prestadores dos serviços. Denotase que a pesquisa realizada tem cunho teórico, exploratório e crítico, desenvolvida à luz do método científico lógico-dedutivo e que conta com diversos procedimentos metodológicos de coleta de informações, com ênfase à pesquisa bibliográfica, legislativa e jurisprudencial. É importante considerar, na investigação, a influência harmonizadora da Constituição e dos novos princípios contratuais, especialmente a incidência da cláusula geral de boafé objetiva.

Palavras-chave: Transporte aéreo. Passageiro. Contrato.

Abstract: The purpose of this article is to analyze passenger

$1 \mathrm{O}$ artigo é resultado parcial dos estudos no projeto "A boa-fé objetiva nos contratos empresariais", desenvolvido pela primeira autora, no curso de Administração da Universidade Estadual do Norte do Paraná (UENP). Versão semelhante foi apresentada no X Seminário Interinstitucional de Mestrados em Direito UEL-UNIMAR, em 2019. O texto final recebeu a colaboração da segunda autora. 
and luggage air transportation contracts, which are legislated by different sources that have many contradictions and antinomies between them, especially when regarding compensations for material and moral damages. Identifying which legislation applies to what case demands a considerable amount of effort from law professionals. Thus, the objective of this paper is to examine divergent doctrinal interpretations and solutions adopted by Brazilian courts. Although the object of study may not be new, the growing use of air travel from the most varied social classes imposes constant pressure on Brazilian law to consolidate fair solutions for both consumers and service providers. This study provides a theoretical, exploratory, and critical analysis from the logical deductive scientific method, which includes several methodological procedures, such as data collection, with emphasis on literature review, and legislative and jurisprudential bibliography. Furthermore, it is important to note, in the investigation, the harmonizing influence of the Constitution and its binding principles, especially regarding the principle of objective good faith.

Keywords: Air Transportation. Passenger. Contracts. 


\section{INTRODUÇÃO}

O transporte consiste em atividade relevante no desenvolvimento da civilização. A extraordinária progressão auferida nos últimos séculos revela a sua importância na dinâmica social e econômica, propiciando a integração entre os povos e favorecendo a circulação de riquezas. No ramo aeronáutico, o avanço da indústria, a redução das intempéries e o cenário econômico garantiram a "democratização" do deslocamento de pessoas, atingindo índices de usuários jamais vistos.

Com o serviço verdadeiramente massificado, o contrato de transporte converte-se em um dos negócios jurídicos mais celebrados na atualidade, de forma a reclamar adequada regulamentação jurídica e a consequente conciliação dos interesses empresariais e consumeristas. A matéria inicialmente se manifestava dispersa em inúmeros textos legislativos, o que proporcionou o advento de uma fecunda jurisprudência.

Diversamente do documento anterior, o Código Civil (BRASIL, 2002), em atendimento ao caput do artigo 178 da Constituição Federal, inovou ao tipificar o contrato de transporte nos artigos 730 a 756. Inseriu inúmeras disposições gerais, seguidas do transporte de pessoas e do transporte de coisas. Quando identificada a relação de consumo, incidem as normas de proteção ao consumidor, mediante sua qualificação como prestação de serviços e os respectivos regimes de responsabilidade civil.

Destarte, observa-se uma multiplicidade de fontes legislativas no transporte aéreo de pessoas e bagagens, em especial quando há transporte internacional: Código Civil, Código de Defesa do Consumidor, Convenção de Montreal, Código Brasileiro de Aeronáutica. O excesso normativo revela um campo fértil para a proliferação de contradições e antinomias, com discrepantes posicionamentos doutrinários e jurisprudenciais. A unidade do sistema, contudo, impõe esforço exegético para a aplicação da lei aos casos concretos, e o recurso à obra pretoriana é uma necessidade permanente.

Portanto, a grande problemática da pesquisa referente ao contrato de transporte e à responsabilidade civil das empresas aéreas é identificar a legislação adequada à situação concreta, particularmente quando envolve o deslocamento internacional. Assim, questiona-se: incide a legislação consumerista - posição dominante nos tribunais pátrios, por mais de duas décadas ou aplicam-se as normas e os tratados internacionais limitadores da indenização, como decidiu o Supremo Tribunal Federal, em 2017 ?

A controversa modificação de posição pelo STF possibilita o tarifamento da indenização e, consequentemente, afasta o princípio da reparação integral informativo do ordenamento jurídico brasileiro. Além disso, no âmbito interno, denota-se a existência de divergências entre o Código Civil e o Código de Defesa do Consumidor. Logo, justifica-se a pesquisa, uma vez que a opção normativa reflete diretamente nos direitos dos usuários e no cenário de má-prestação de serviços, como extravio de bagagens, atraso e cancelamento de voos, prática do overbooking, entre outras situações que ocasionam danos patrimoniais e extrapatrimoniais aos usuários. 
Com base no problema explanado, o objetivo do trabalho é a análise do contrato de transporte de pessoas e bagagens, por via aérea, sob o enfoque legislativo, doutrinário e jurisprudencial. $\mathrm{O}$ texto inicia pela concisa investigação histórica; aborda as antinomias relativas aos limites legais da indenização por danos materiais e morais; evoca a responsabilidade civil do transportador e encerra com alguns direitos e deveres dos usuários do transporte aéreo.

Para tanto, a investigação tem cunho teórico, exploratório e crítico, desenvolvida à luz do método científico lógico-dedutivo e que conta com diversos procedimentos de coleta de informações. Sobressai o exame da legislação nacional (adota como documentos principais o Código Civil, o Código de Defesa do Consumidor e o Código Brasileiro de Aeronáutica) e estrangeira (portuguesa, italiana, francesa e alemã), bem como das normas e dos tratados internacionais. Expõe os discrepantes entendimentos doutrinários presentes em obras jurídicas e artigos científicos. Enfim, analisa os julgados paradigmáticos da temática dos tribunais superiores e as decisões proferidas pelos tribunais de segundo grau.

Em suma, confronta o conhecimento teórico com as decisões judiciais, elencando conclusões parciais e não definitivamente sedimentadas, sem esgotar tal temática de tamanha envergadura.

\section{DELINEAMENTOS HISTÓRICOS}

O transporte surgiu nos primórdios da civilização, decorrente da necessidade de intercâmbio de coisas. De todos os meios existentes, o transporte marítimo alcançou primeiramente o desenvolvimento, graças ao empenho dos fenícios (NADER, 2010, p. 370-371). À medida que a navegação passou a ser praticada por outros povos, eclodiram normas reguladoras como as Leis de Eshnunna (GILISSEN, 2001, p. 64), o Código de Hamurabi, o Código de Manu e a Lex Rhodia de Iactu (MONTEIRO; MALUF; SILVA, 2009, p. 342), demonstrando a preocupação das sociedades antigas com o traslado de mercadorias.

O contrato de transporte de pessoas, contudo, é considerado fenômeno recente na história ${ }^{2}$, uma vez que, anteriormente, era raro quem não tivesse interesse nas cargas. Foi somente na segunda metade do século XIX que as modificações nas condições de deslocamento e as circunstâncias políticas e econômicas impulsionaram a modalidade negocial (RIPERT, 1929, p. 950). Referido século foi essencial para o aperfeiçoamento de aeronaves e o consequente desenvolvimento do transporte aéreo.

A idealização da máquina aérea como veículo para fins desportivos incentivou pequenos fabricantes. Com o advento da Primeira Guerra Mundial, a aventura e o desporto deram lugar à utilização bélica da aviação e, ao final do conflito, empregou-se a infraestrutura existente para a exploração de serviços aéreos postais e comerciais (MORSELLO, 2007, p. 44-47).

O inegável avanço da aviação no período, porém, não configurava o transporte de massa.

2 "Quem, naquêles tempos tão afastados, precisava de transportar-se, ou tomava emprestado animais ou veículos, que eram raros, a amigos, ou os alugavam mais aquêles, do que a estes, para aquêle objetivo" (FERREIRA, 1944, p. 511). 
Foi a produção de aeronaves em larga escala, advinda da Segunda Guerra Mundial e seguida da criação de novas rotas comerciais, que propiciou o uso do transporte aéreo de passageiros por mercado cativo elitizado e por homens de negócios, na década de cinquenta (MORSELLO, 2007, p. 47-48).

A expansão do turismo internacional iniciada nos anos sessenta modificou a situação: o serviço, que a princípio beneficiava um pequeno grupo de privilegiados, difundiu-se e atualmente serve milhões de consumidores. $\mathrm{O}$ avião possibilita locomoção rápida e verdadeiramente segura (BENJAMIN, 1998, p. 33-44). Nos dizeres de José de Aguiar Dias (2012, p. 231), um dos milagres atuais é, sem dúvida, "o surto prodigioso da aeronave aérea".

Sob o aspecto jurídico, o desenvolvimento do transporte aéreo civil impunha investimentos vultosos e, em virtude dos altos riscos existentes à época, revelou-se fundamental a edição de normas aptas a proteger o setor aeronáutico. "Tendo em vista, ademais, a célere transposição de fronteiras internacionais, afigurava-se imprescindível editar um diploma legal uniforme em vários países" (MORSELLO, 2015, p. 113-114). Com base nos fatores descritos, em 1929, assinou-se a Convenção de Varsóvia para unificação das regras relativas ao transporte aéreo internacional, que entrou em vigor em 1933, considerado um avanço do direito privado uniforme. No mês de maio de 1999, em Montreal, um novo documento foi firmado e, em 2003, entrou em vigor a Convenção de Montreal, que liga 107 estados participantes (CACHARD, 2015, p. 19-20).

No Brasil, o transporte explorado em grande escala ensejou a realização de negócios em condições diversas das existentes (GOMES, 2009, p. 373). O contrato de transporte, que antes se confundia com a locação de serviços ou com a empreitada, hoje conta com regras próprias, diferenciando o transporte de coisas e de pessoas, segundo as particularidades das várias modalidades (VENOSA, 2012, p. 336): por via fluvial, marítima, terrestre e aérea, bem como por meio de navios, estradas de ferro, automóveis, aviões, metrô, ônibus, barcas e outros (DIAS, 2012, p. 202).

O Código Civil brasileiro disciplina o contrato de transporte no artigo 730 e seguintes, regulamentando o transporte de pessoas e de coisas. Esse documento segue a mesma ordem do Código Civil italiano, que trata do assunto no capítulo VIII, referindo-se, também, ao contrato de pessoas (artigo 1.681 e seguintes) e contrato de coisas (artigo 1.683 e seguintes) $)^{3}$. Portanto, a inovação trazida na legislação civil atual regula o contrato de transporte de forma específica, incluindo-o no rol dos contratos típicos, com regras próprias (prioritariamente) e que podem ser complementadas pela legislação especial (GONÇALVES, 2017, p. 292).

Quanto às fontes normativas do transporte aéreo de pessoas e bagagens, diferencia-se a modalidade internacional da doméstica. No âmbito do transporte aéreo internacional, considerado como aquele que liga dois países ${ }^{4}$, foram editados vários diplomas até o advento da Convenção de ontreal ${ }^{5}$. O transporte aéreo doméstico, prestado no interior do país, é objeto da Lei $\mathrm{n}^{\mathrm{o}} 7.565$, de

3 Confira o Codice Civile (ITALIA, 2018).

4 Segundo Marco Fábio Morsello (2015, p. 118) “considera-se transporte aéreo internacional aquele que o ponto de partida inicial e o ponto de destino final sejam situados em Estados distintos ou em que um ponto de escala esteja situado em um Estado diferente do Estado onde se situa o ponto de partida e de destino."

5 A Convenção de Varsóvia foi editada em 12 de outubro de 1929 e expressamente promulgada no Brasil, pelo 
19 de dezembro de 1986, denominada Código Brasileiro de Aeronáutica (DINIZ, 2006, p. 434). Paralelamente às legislações específicas, é possível extrair princípios gerais do Código de Defesa do Consumidor (quando caracterizada relação de consumo) e do Código Civil (BRASIL, 2002).

Do exposto, é possível concluir que a regulamentação interna do transporte aéreo é marcada pela convivência de um anacrônico regime legal adequado à pretérita ordem pública de direção, instituído no início do século XX, quando a indústria aeronáutica encontrava-se "na sua infância", e de um regime recente, caracterizado pela responsabilidade civil moderna e por novos princípios contratuais (MORSELLO, 2007, p. 91), em especial pela incidência da cláusula geral da boa-fé objetiva.

\section{O CONTRATO DE TRANSPORTE AÉREO}

O contrato é uma 'conjugação entre consensos' (MARTINS-COSTA, 2018, p. 115). Nesse sentido, o Código Civil Francês, no artigo 1.101 dispõe que "o contrato é um acordo de vontades entre duas ou mais pessoas, destinado a criar, modificar, transmitir ou extinguir obrigações."6

No tocante ao contrato de transporte, o artigo 730 do Código Civil de 2002 adotou definição semelhante à de Francisco Cavalcanti Pontes de Miranda, ao estatuir que "Pelo contrato de transporte alguém se obriga, mediante retribuição, a transportar, de um lugar para outro, pessoas ou coisas" (BRASIL, 2002)7. O objeto principal da avença é a transladação de pessoa ou bem, embora o contrato possa abranger, como acessório, a locomoção da bagagem ou de animal e outras utilidades, como acomodação e refeições nos percursos mais demorados (ASSIS, 2005, p. 318). O negócio ocorre entre o transportador e a pessoa a ser transportada (viajante ou passageiro) ou a pessoa que entrega o objeto (remetente ou expedidor).

A natureza jurídica do contrato de transporte variou no transcorrer dos tempos: foi equiparada à locação de serviços, à empreitada, ${ }^{8}$ ao fretamento, ao arrendamento, ${ }^{9}$ ao mandato mercantil e ao depósito. $\mathrm{Na}$ atualidade, muitos autores consideram o transporte um contrato sui generis $^{10}$. Após a regulamentação civil, transformou-se em negócio típico, autônomo, diferindo das outras figuras do direito contratual. Por conseguinte, o contrato de transporte é "um negócio sobre realização de uma obra especial, em que assume obrigação de resultado, ficando a cargo do

Decreto $\mathrm{n}^{\mathrm{0}} 20.704$, de 24 de novembro de 1931. Recebeu alterações (e complementos) do Protocolo de Haia, de 28 de setembro de 1955, ratificado em 16 de junho de 1964 e promulgado pelo Decreto $\mathrm{n}^{\circ} 56.463$, de 15 de junho de 1965; da Convenção de Guadalajara, de 1961, ratificada em 08 de fevereiro de 1967 e promulgada pelo Decreto $\mathrm{n}^{\circ}$ 60.967, de 7 de julho de 1967 e dos Protocolos de Montreal, de 1975, aprovado pelo Decreto Legislativo ${ }^{\circ} 22$, de 28 de maio de 1979, com ratificação dos Protocolos nos 1 e 2 em 27 de julho de 1979, e promulgação de todos pelo Decreto $n^{\circ}$ 2.860, de 14 de junho de 1998 (Cf. MORSELLO, 2007, p. 53-90). A Convenção de Montreal encontra-se em vigor no Brasil, por meio do Decreto $n^{\circ} 5.910$, de 27 de setembro de 2006 (MORSELLO, 2015, p. 117).

6 No original, o artigo 1.101 do Código Civil Francês dispõe: "Le contrat est un accord de volontés entre deux ou plusieurs personnes destiné à créer, modifier, transmettre ou éteindre des obligations." (RÉPUBLIQUE FRANÇAISE, 2020).

7 Segundo Francisco Cavalcanti Pontes de Miranda (2012, p. 63), o contrato de transporte é "o contrato pelo qual alguém se vincula, mediante retribuição, a transferir de um lugar para outro pessoa ou bens".

8 Roberto de Ruggiero (2005, p. 462-465) trata do contrato de transporte dentro do tópico destinado à locação de obra ou contrato de empreitada. O autor firma que "o contrato de transporte não tem uma natureza diversa das outras formas de locação de serviços".

9 Manuel Albaladejo (1975, p. 264) trata do contrato de transporte na seção destinada ao "Arrendamiento de servicios y obras".

10 Nesse sentido, confira: Morsello (2006, p. 386-407). 
transportador os riscos do empreendimento". Classifica-se como bilateral, consensual, oneroso, não formal e, em regra, de adesão (THEODORO JÚNIOR, 2003, p. 11-26).

Trata-se de contrato bilateral sinalagmático, porque cria obrigações interdependentes para ambas as partes; de forma livre (admite-se até a relação contratual de fato, estabelecida com um incapaz, desde que observado o Estatuto da Criança e do Adolescente) e de duração, porquanto não executável de maneira instantânea. É consensual (embora pese opiniões contrárias), não se exigindo o embarque do passageiro ou a entrega da mercadoria para sua formação, visto que tais atos são de execução da avença (GODOY, 2008, p. 682). Frise-se que o artigo 730 previu expressamente a onerosidade e, assim, afastou o deslocamento por mera cortesia.

A respeito da onerosidade do contrato, o legislador, no artigo 736 do Código Civil, acompanhou a doutrina alienígena (como o direito português ${ }^{11}$ e o direito italiano ${ }^{12}$ ) e o entendimento da jurisprudência consolidada na Súmula 145 do Superior Tribunal de Justiça ${ }^{13}$. Excluiu do campo de abrangência o denominado transporte gratuito, feito por amizade ou cortesia. Na hipótese, advindo um dano, a responsabilidade será extracontratual e o transportador só responderá quando incorrer em dolo ou culpa grave (GUIMARÃES, 2007, p. 86-87), como já decidido pelo Tribunal de Justiça de São Paulo ${ }^{14}$. Aliás, José Fernando Simão (2014) destaca a função social da carona que deve ser estimulada por reduzir o número de veículos nas ruas, fato este que melhora o trânsito e o meio ambiente. ${ }^{15}$

O parágrafoúnico do artigo em comento, porém, evidencia que determinadas “gratuidades", se vinculadas aos fins econômicos, não elidem a tipificação contratual ${ }^{16}$. É o caso dos bilhetes adquiridos com milhagem, em que há a aplicação do Código de Defesa do Consumidor e a responsabilidade do transportador decorrente da má prestação do serviço é objetiva ${ }^{17}$. Igualmente, não é reputado desinteressado o transporte coletivo disponibilizado ao idoso sem pagamento de passagem, "pois em verdade há custo que indica não agir o concessionário por mera cortesia." (GODOY, 2008, p. 693).

Portanto, verifica-se que o artigo 736 do Código Civil adotou a responsabilidade

11 O Código Civil português, no artigo 504.3 prevê que "No caso de transporte gratuito, a responsabilidade abrange apenas os danos pessoais da pessoa transportada."

12 No direito italiano, pela redação do artigo 1.681 do Estatuto Civil, admite-se a aplicação da responsabilidade do transportador também aos contratos gratuitos: "Le norme di questo articolo si osservano anche nei contratti di trasporto gratuito." (ITALIA, 2020).

13 Segundo a Súmula no 145 do Superior Tribunal de Justiça: "No transporte desinteressado, de simples cortesia, o transportador só será civilmente responsável por danos causados ao transportado quando incorrer em dolo ou culpa grave." (MELO, 2016).

14 TJSP. Apelação Cível 9119532-78.2001.8.26.0000. Relator (a):Jayme Queiroz Lopes (SÃO PAULO, 2019).

15 No entanto, o tema não é pacífico: há autores que sustentam a responsabilidade objetiva daquele que dá carona-como Flávio Tartuce (2018, p. 1.092); outros alegam que basta culpa, em qualquer de seus graus, para a responsabilização - como é o caso do desembargador Marco Aurélio Bezerra de Melo (2016).

16 "Observado o Enunciado 369 do CJF, no transporte aéreo, nacional e internacional, a responsabilidade do transportador em relação aos passageiros gratuitos, que viajarem por cortesia, é objetiva, devendo atender à integral reparação de danos patrimoniais e extrapatrimoniais" (Enunciado 559) (CONSELHO DA JUSTIÇA FEDERAL, [2006?]).

17 Apelação. Transporte aéreo. Aquisição de passagem aérea através de programa de milhagem. Bilhete não emitido por falha sistêmica, conforme constatado no momento do embarque. Má prestação dos serviços configurada. Aplicação do CDC. Responsabilidade objetiva. Danos materiais e morais. Configuração. Indenização pelos danos morais experimentados bem fixada em atendimento aos critérios da proporcionalidade e razoabilidade, bem como ao caráter compensatório pelo abalo sofrido e inibitório da reiteração na má prestação de serviços. Sentença confirmada por seus próprios fundamentos, nos termos do art. 252 do RITJS̃P. Recurso desprovido. TJSP. Apelação Cível 1023703-70.2019.8.26.0100. Relator (a):Flávio Cunha da Silva. (SÃO PAULO, 2020). 
extracontratual ou aquiliana no transporte puramente gratuito ou benévolo, e a responsabilidade contratual, com cláusula de garantia, no transporte oneroso ou aparentemente gratuito (GONÇALVES, 2017, p. 305).

O transporte, na maioria das vezes, é um contrato de adesão, ou seja, não está presente a plena discussão das cláusulas (TARTUCE, 2019, p. 680). Ao negócio padronizado, com cláusulas pré-elaboradas pelo transportador, a interpretação será mais favorável ao aderente, nos termos do artigo 423 do Código Civil e do artigo 47 do Código de Defesa do Consumidor. ${ }^{18}$

Explanadas as considerações prévias e indispensáveis ao contrato de transporte e ao transporte de pessoas ${ }^{19}$, adentra-se na temática que é objeto do presente estudo: transporte aéreo de pessoas e de bagagens. A respeito desse subtipo, o artigo 222 do Código Brasileiro de Aeronáutica apresenta o contrato de transporte aéreo de passageiros como aquele pelo qual o transportador se obriga, mediante contraprestação pecuniária, a transportar pessoas e bagagens, por via aérea.

Para caracterizar o transporte aéreo, além da transferência de pessoas ou de coisas de um lugar para outro, impõe-se a existência do veículo de transporte apto à navegação aérea. É contrato bilateral, consensual e oneroso. Acrescenta Luiz Felipe Salomão (2016, p. 203) que o contrato é também comutativo, por adesão e visa o resultado.

Quanto ao contrato de transporte de bagagem, este consiste em acessório ao de pessoa e quando alguém compra um bilhete, terá o direito de levar consigo a bagagem e o transportador deverá deslocá-la, cabendo ao passageiro o pagamento do excesso não contratado (GONÇALVES, 2017, p. 302).

Em relação ao tipo contratual, a Convenção de Montreal e o Código Brasileiro de Aeronáutica permanecem plenamente em vigor e convivem de maneira harmoniosa com o Código Civil e com o Código de Defesa do Consumidor, salvo o conflito aparente de normas restrito à responsabilidade civil dos transportadores. Ao contrário do ordenamento pátrio, a Convenção de Montreal impõe a responsabilidade subjetiva (com presunção de culpa), limitada e com proibição expressa de inserção de cláusulas convencionais, de modo a eximir ou reduzir os limites indenizatórios nela fixados (MORSELLO, 2015, p. 115).

Frente à contradição, se a relação é admitida como de consumo, as empresas prestadoras de serviços de transporte aéreo alegam o artigo 178 da Constituição Federal, objetivando a aplicação da Convenção de Montreal e do Código Brasileiro de Aeronáutica. Por sua vez, os passageiros sustentam a aplicação do Código de Defesa do Consumidor, por se tratar de norma protetiva, mais benéfica. Ademais, para inflamar a controvérsia, o artigo 732 do Código Civil estatui a sua primazia sobre o conteúdo de qualquer outra norma referente ao contrato de transporte. Doutrina e jurisprudência discrepam a respeito do tema, como demonstra o tópico subsequente.

18 "O contrato de adesão, mencionado nos arts. 423 e 424 do novo Código Civil, não se confunde com o contrato de consumo" (Enunciado 171) (CONSELHO DA JUSTIÇA FEDERAL, [2002?a]).

19 O teor do artigo 730 do Código Civil distingue o contrato de transporte de pessoas e o de mercadorias. O primeiro caracteriza-se "com a assunção, pela empresa exploradora, da obrigação de conduzir passageiros e bagagens, de uma localidade para outra, mediante satisfação do preço correspondente, e obediente ao respectivo itinerário." (BITTAR, 2008. p. 131). 


\section{AS (APARENTES) ANTINOMIAS NA REGULAMENTAÇÃO DO TRANSPORTE AÉREO}

No tocante aos limites indenizatórios fixados na Convenção de Montreal e no Código Brasileiro de Aeronáutica, a doutrina e os tribunais pátrios dividem-se em duas correntes diametralmente opostas.

Eros Roberto Grau (2011, p. 411-414) sustenta a total possibilidade de limitação da indenização. Para o jurista, o Código de Defesa do Consumidor é norma geral, que trata amplamente da defesa do consumidor, enquanto a Convenção de "Varsóvia" e o Código Brasileiro de Aeronáutica são normas especiais, por regularem a relação entre os agentes econômicos e seus clientes em determinado setor da economia. Logo, havendo divergência no caso concreto e considerado que a lei especial prevalece sobre a geral, serão aplicadas as normas específicas: a Convenção de "Varsóvia" e o Código Brasileiro de Aeronáutica, mesmo que sejam anteriores ao Código de Defesa do Consumidor. Humberto Theodoro Júnior (2003, p. 11-26) está assente com referido entendimento.

Posicionamento contrário adota Antônio Herman de Vasconcellos e Benjamin (1998, p. 33-44), para quem os limites indenizatórios do transporte aéreo violam preceitos constitucionais, atentando contra a dignidade humana, a justiça e a solidariedade social. Enfim, o Código de Defesa do Consumidor afasta a aplicação da Convenção de "Varsóvia" e do Código Brasileiro de Aeronáutica, seja pelo caráter protetório que o torna especialíssimo, seja pela posteridade de publicação.

A responsabilidade civil do transportador aéreo já foi objeto de análise pelo Supremo Tribunal Federal. Como explica Flávio Tartuce (2018, p. 1.077):

[...] a questão a respeito das Convenções de Varsóvia e de Montreal alterou-se no âmbito da jurisprudência superior nacional, uma vez que, em maio de 2017, o Pleno do Supremo Tribunal Federal acabou por concluir pelas suas prevalências sobre o Código de Defesa do Consumidor, lamentavelmente.

A solução se deu pelos critérios da especialidade e cronológico. ${ }^{20}$ Por sua vez, o Superior Tribunal de Justiça tem seguido a solução da Corte Constitucional brasileira (TARTUCE, 2019, p. 684).

$\mathrm{O}$ caso concreto decidido no RE 636311/RJ dizia respeito à responsabilidade civil do transportador aéreo por extravio de bagagem, cujo texto da Convenção prevê um limite máximo de mil Direitos Especiais de Saque (DES), equivalente a R \$ 4.561,00, ao tempo do julgamento. Ao comentar o assunto, Bruno Miragem (2018, p. 549) critica a posição adotada no julgado:

A tese fixada no julgamento, contudo, refere-se, genericamente, à prevalência das 'normas e os tratados internacionais limitadores da responsabilidade das 
transportadoras aéreas de passageiros', não distinguindo entre a natureza dos danos, se patrimoniais ou extrapatrimoniais (assim, por exemplo, o dano morte do consumidor em razão de acidente aéreo).

Nessa linha, em julgado recente (decisão noticiada em 19/06/2020) o STJ entendeu que:

Embora seja norma posterior ao Código de Defesa do Consumidor (CDC) e constitua legislação especial em relação aos contratos de transporte aéreo internacional - com prevalência, segundo o Supremo Tribunal Federal, sobre a legislação consumerista interna -, a Convenção de Montreal não pode ser aplicada para limitar a indenização devida aos passageiros em caso de danos morais decorrentes de atraso de voo ou extravio de bagagem, tendo em vista que o tratado internacional alcança apenas as hipóteses de dano material. Com base nesse entendimento, a Terceira Turma do Superior Tribunal de Justiça (STJ) manteve acórdão do Tribunal de Justiça do Rio Grande do Sul (TJRS) que, ao analisar ação por extravio de bagagem em voo internacional, confirmou a fixação de danos morais de R $\$ 8$ mil para cada passageiro, com base no CDC, e danos materiais conforme as notas fiscais dos gastos realizados pelos requerentes enquanto estiveram sem as malas, nos limites da Convenção de Montreal. No recurso ao STJ, a companhia aérea afirmou que os conflitos sobre extravio de bagagem deveriam ser resolvidos pelas regras dos tratados internacionais ratificados pelo Brasil. Por isso, defendeu que fosse observado o parâmetro máximo da Convenção de Montreal para indenizações, cobrindo tanto os danos materiais quanto os morais (BRASIL. 2020). ${ }^{21}$

Ou seja, o Superior Tribunal de Justiça aplicou a legislação consumerista para os danos morais decorrentes do extravio de bagagem e reservou a incidência da Convenção de Montreal somente para os danos materiais. Com efeito, o STJ afastou a tese fixada pelo STF no julgamento do Recurso Extraordinário $n^{\circ} 636.331 / \mathrm{RJ}$, que entendeu pela prevalência da Convenção sobre o Código de Defesa do Consumidor para qualquer espécie de dano. ${ }^{22}$

Por fim, é possível observar alguns pontos de desarmonia entre o Código de Defesa do Consumidor e o Código Civil de 2002 em matéria de transportes. É certo que, ao determinar que o contrato de transportes seja necessariamente oneroso, o Código Civil abrangeu inúmeras relações de transporte que são de consumo. A prevalência de um ou de outro documento legislativo,

21 Vide notícia "Para Terceira Turma, dano moral a passageiro de voo internacional não se submete à Convenção de Montreal", de 19.06.2020. (BRASIL. 2020).

22 Vide REsp 1842066/RS: CIVIL E PROCESSUAL CIVIL. RECURSO ESPECIAL. RECURSO MANEJADO SOB A ÉGIDE DO NCPC. AČ̃̃O INDENIZATÓRIA. TRANSPORTE AÉREO INTERNACIONAL. DIREITO DO CONSUMIDOR. EXTRAVIO DE BAGAGEM. PEDIDO DE REPARAÇÃO POR DANOS MATERIAIS E MORAIS. NORMAS E TRATADOS INTERNACIONAIS. CONVENÇÃO DE MONTREAL. LIMITAÇÃO DA RESPONSABILIDADE CIVIL DA TRANSPORTADORA APENAS QUANTO AOS DANOS MATERIAIS. APLICAÇÃO DO CÓDIGO DE DEFESA DO CONSUMIDOR EM RELAÇÃO AOS DANOS MORAIS. RECURSO ESPECIAL NÃO PROVIDO. (...) 2. O STF, no julgamento do RE $\mathrm{n}^{\circ}$ 636.331/RJ, com repercussão geral reconhecida, fixou a seguinte tese jurídica: Nos termos do artigo 178 da Constituição da República, as normas e os tratados internacionais limitadores da responsabilidade das transportadoras aéreas de passageiros, especialmente as Convenções de Varsóvia e Montreal, têm prevalência em relação ao Código de Defesa do Consumidor. 3. Referido entendimento tem aplicação apenas aos pedidos de reparação por danos materiais. 4. As indenizações por danos morais decorrentes de extravio de bagagem e de atraso de voo não estão submetidas à tarifação prevista na Convenção de Montreal, devendo-se observar, nesses casos, a efetiva reparação do consumidor preceituada pelo CDC. 5. Recurso especial não provido. (REsp 1842066/RS, Rel. Ministro MOURA RIBEIRO) (BRASIL, 2020). 
igualmente, divide juristas.

Cláudia Lima Marques (2005, p. 447-448) ensina que a relação de transporte de pessoas ou passageiros, quando de consumo, deve ser regulada pelo Código de Defesa do Consumidor, em diálogo com o Código Civil. Havendo conflito, a preferência será pela aplicação do primeiro, atendendo à proteção constitucional do consumidor. Consoante à autora, a utilização do Código Civil "contra" os consumidores implicaria enorme injustiça no sistema e um privilégio inconstitucional para os fornecedores de serviços de transporte.

$\mathrm{Na}$ mesma linha, a doutrina aponta a necessidade, diante de tantas fontes normativas que regulamentam a matéria, de que ocorra um diálogo entre elas, em especial entre o Código Civil e o Código de Defesa do Consumidor. Flávio Tartuce aponta a necessidade de um diálogo de "complementaridade, com aplicação simultânea e coordenada das duas leis" (SCHREIBER et al., 2019, p. 438).

Marco Fábio Morsello (2006, p. 399-401), autor da mais completa obra sobre responsabilidade civil no transporte aéreo, sustenta que, uma vez confirmada relação de consumo, prepondera o diploma consumerista porque, além da proteção dos direitos fundamentais do consumidor, vige a maior especialidade legislativa, não tendo a norma geral posterior o condão de preponderar diante da norma especial anterior. Coaduna com a lição Renan Lotufo (2002, p. 205214), ao ensinar que o Código Civil não revoga o Código de Defesa do Consumidor.

Posicionamento diverso é exposto por Carlos Roberto Gonçalves (2003, p. 160), respaldado no artigo 732 do Código Civil. Para o jurista, a prevalência é do Código Civil, quando em confronto com o Código de Defesa do Consumidor, visto que o primeiro regulamenta especificamente o transporte de pessoas e o segundo, de forma geral, as relações de consumo (GONÇALVES, 2012, p. 490). Assim, "as normas do Código Civil preponderam sobre as demais que dispõem a respeito do contrato de transporte. As outras regras são subsidiárias" (GONÇALVES, 2017, p. 296). Rui Stoco (2011, p. 378) e Rui Rosado de Aguiar Júnior (2003) comungam de idêntico entendimento.

Observa-se que não há como perdurar esse último entender. Considerada a tutela constitucional do consumidor, com vistas à redução de sua situação de particular vulnerabilidade e o critério da especialidade, deverá prevalecer a legislação protetiva. É certo que o Código Civil e o Código de Defesa do Consumidor devem ser considerados complementares na promoção da solidariedade e do personalismo constitucionais, mas havendo divergência, aplicar-se-á o segundo ao caso concreto ${ }^{23}$. Esclarece Gustavo Tepedino, Konder e Bandeira (2020, p. 409) que "sempre que o transportador for um prestador de serviço e o contratante for consumidor, segundo a definição legal, o diploma especial será aplicável”.

Vale notar que, frente às inúmeras leis ordenadoras do transporte aéreo, o intérprete deverá sujeitar-se ao influxo da força unificadora da Constituição, sem perder de vista a nova principiologia contratual, que não é diversa no Código Civil e no Código de Defesa do Consumidor: garantir

23 Dispõe o Enunciado 369 CJF/STJ: “Diante do preceito constante no art. 732 do Código Civil, teleologicamente e em uma visão constitucional de unidade do sistema, quando o contrato de transporte constituir uma relação de consumo, aplicam-se as normas do Código de Defesa do Consumidor que forem mais benéficas a este." (CONSELHO DA JUSTIÇA FEDERAL, [2002?b]). 
e fomentar a função social do contrato, a boa-fé objetiva e o equilíbrio contratual; assegurar a dignidade humana, o solidarismo e a justiça nas relações entre as pessoas (GODOY, 2008, p. 685).

Cumpre realçar a incidência da boa-fé objetiva nos contratos de transporte, inclusive por via aérea, pois sua finalidade é proporcionar o bom andamento das relações jurídicas, além de servir de fonte para a elaboração de regras jurídicas (TOMASEVICIUS FILHO, 2020, p. 92). Assim, pode-se dizer que "a boa-fé objetiva é uma regra de conduta que consiste no dever de atuar de acordo com os modelos (standards) socialmente reconhecidos de legitimidade e lealdade." (MORSELLO, 2019, p. 181).

Anderson Schreiber (2016, p. 53) explica que a boa-fé objetiva também é conhecida como boa-fé contratual, tendo sido amplamente desenvolvida pela doutrina e jurisprudência alemãs (após 1896), com base no $§ 242$ do BGB ${ }^{24}$. Ainda no direito estrangeiro, cita-se que o Código Civil francês, no artigo 1.104 dispõe que os contratos devem ser negociados, formados e executados de boa-fé, sendo tal disposição, de ordem pública ${ }^{25}$.

O Código Civil brasileiro regula a boa-fé objetiva no artigo 113, no que tange à interpretação dos negócios jurídicos, e, mais especificamente, na parte contratual, no artigo 422, mencionando a necessidade dos contratantes respeitarem o princípio da boa-fé tanto na fase da conclusão como na da execução do contrato. Desta feita, trata-se de "um modelo de conduta social ou um padrão ético de comportamento, impondo, concretamente, a todo cidadão que, na sua vida de relação, atue com honestidade, lealdade e probidade" (SANSEVERINO, 2018, p. 184).

Assim sendo, mesmo nos transportes low cost, segundo Marco Fábio Morsello (2019, p. 178), “não poderá descurar o núcleo duro mínimo de proteção ao usuário, substituindo, pois, in casu, a aplicação da boa-fé objetiva". Sobre a aplicabilidade da boa-fé aos contratos de transporte, afirma o autor que "nesse contexto, emergem novos paradigmas para sua aplicação, aptos a dar efetividade à obrigação de proteção ao passageiro, colmatando lacunas das Convenções reguladoras do transporte aéreo civil internacional.” (MORSELLO, 2019, p. 181).

Em suma, tomando por base o arcabouço jurídico que regula o contrato de transporte aéreo de passageiros e bagagens, a maior dificuldade é identificar a normativa correta ao caso concreto: no deslocamento internacional, aplica-se a Convenção de Montreal ou o Código de Defesa do Consumidor; no transporte doméstico, o Código Civil ou Código de Defesa do Consumidor.

\section{OBRIGAÇÕES E RESPONSABILIDADES DO TRANSPORTADOR}

Compete ao transportador aéreo o dever de "apanhar" o passageiro em determinado local, conduzi-lo são e salvo ao destino e respeitar os horários de embarque e de desembarque previamente estabelecidos (STOCO, 2011, p. 337). Responderá por acidentes, atrasos e outros efeitos danosos ocorridos com o passageiro e sua bagagem (BITTAR, 2008, p. 131).

24 Vide $\$ 242$ BGB: "Der Schuldner ist verpflichtet, die Leistung so zu bewirken, wie Treu und Glauben mit Rücksicht auf die Verkehrssitte es erfordern." (BUNDESMINISTERIUM, 2020). Conforme tradução livre: "O devedor é obrigado a efetuar a execução conforme exigido a boa-fé com o devido respeito a costume".

25 (Tradução livre). No original: “Article 1104: Les contrats doivent être négociés, formés et exécutés de bonne foi. Cette disposition est d'ordre public". 
Quanto ao âmbito espacial-temporal da responsabilidade do transportador, o artigo 17 da Convenção de Montreal e o artigo 233 do Código Brasileiro de Aeronáutica consideram não apenas os danos ocorridos a bordo da aeronave, mas igualmente os que acontecem no curso das operações de embarque e de desembarque ${ }^{26}$, como quando o passageiro está na fila para a utilização de ground handling services (serviços com equipamentos de transporte por superfície na área dos aeroportos) ou de fingers (passarelas telescópicas) (MORSELLO, 2007, p. 166).

Desse modo, calcado em uma interpretação extensiva do conceito de embarque e desembarque trazido pelo Código Brasileiro de Aeronáutica, é possível afirmar que "a responsabilidade do transportador inicia quando o passageiro se submete às ordens e determinações de preposto da companhia aérea para proceder ao embarque, em área destinada para tanto, finalizando quando atinge o hall de chegada (com livre acesso ao público)" (MORSELLO, 2007, p. 169). O translado até o aeroporto corre por conta e risco do passageiro, assim como ato ilícito que possa ocorrer nas dependências do aeroporto (ASSIS, 2005, p. 318).

O transporte é considerado obrigação de resultado (ALVIM, 1995, p. 341), sendo a responsabilidade contratual. Para a grande maioria dos doutrinadores, a responsabilidade é objetiva. Prescinde, pois, da verificação da culpa, sendo suficiente provar o transporte e o dano para caracterizar a responsabilidade por inadimplemento contratual (GONÇALVES, 2003, p. 147).

Segundo Enzo Roppo (1988, p. 287), Carlos Alberto Bittar (2008, p. 130) e Araken de Assis (2005, p. 323-327), a responsabilidade do transportador revela-se objetiva em razão do risco da atividade. Rui Stoco (2011, p. 335-337) defende a responsabilidade objetiva quando a atividade explorada está ao abrigo do artigo $37, \S 6^{\circ}$ da Constituição Federal27 ${ }^{27}$ E, não há como desconsiderar a responsabilidade independente de culpa prevista no Código de Defesa do Consumidor, quando se tratar de relação de consumo (GUIMARÃES, 2007, p. 135). Neste sentido, explica Flávio Tartuce (2018, p. 1.082) que o contrato de transporte é identificado por uma obrigação de resultado do transportador, em razão do artigo 14 do Código de Defesa do Consumidor, bem como do artigo 734 do Código Civil.

O artigo 734 expressa a obrigação do transportador de conduzir o passageiro são e salvo. É a denominada cláusula de incolumidade, ínsita à espécie (DIAS, 2012, p. 207-215): “se um passageiro contrata uma empresa para levá-lo, subentende-se que ele quer chegar por inteiro e não "em tiras"” (MONTEIRO; MALUF; SILVA, 2009, p. 346). Referido dever de proteção impossibilita a inserção de cláusula excludente de responsabilidade, sob pena de nulidade. O legislador absorveu entendimento consubstanciado na Súmula $n^{\circ} 161$ do Supremo Tribunal Federal e a disposição acompanha, ademais, o artigo 1.681 do Código Civil italiano, que prevê: "São nulas as cláusulas

26 O artigo 233 do Código Brasileiro de Aeronáutica estabelece o que é embarque e desembarque. O embarque ocorre quando o passageiro transpõe a área preambular pública e entra numa área interna de espera coletiva, reservada aos que vão viajar e aos funcionários do aeroporto e das empresas, ou em salas destinadas a cada voo. O desembarque inicia-se com a saída de bordo da aeronave e termina no ponto de interseção da área interna do aeroporto e da área aberta ao público em geral (PACHECO, 1990, p. 452-453).

27 Nos termos da Constituição Federal de 1988, os serviços de transporte aéreo são privativos da União (artigo 21, XII, c), que podem explorá-lo diretamente ou mediante autorização, concessão ou permissão. Assim, aplicando o artigo $37, \S 6^{\circ}$ da Carta, a responsabilidade das pessoas jurídicas, na exploração do transporte aéreo que interessa ao Estado, será objetiva (STOCO, 2011, p. 335-337). 
que limitam a responsabilidade do transportador por danos que ocorrem aos viajantes" ${ }^{28}$.

Por outro lado, o parágrafo único do artigo 734 do Código Civil faculta a exigência de declaração do valor da bagagem com o intuito de fixar o montante da indenização ${ }^{29}$. Para tal finalidade, mostra-se lícito que o transportador vistorie as bagagens, nos termos do estabelecido pelo artigo 234, $\S 2^{\circ}$ do Código Brasileiro de Aeronáutica. Existente o consenso dos figurantes quanto ao valor declarado, valerá ele como limite máximo da indenização em caso de destruição ou de perda total da bagagem (ASSIS, 2005, p. 331).

Em que pesem opiniões contrárias, referido posicionamento do legislador pátrio é condizente com os ditames da boa-fé objetiva, uma vez que impede o enriquecimento indevido do passageiro. Não há, portanto, atentado contra o artigo $6^{\circ}$, VI e VIII do Código de Defesa do Consumidor. Ao contrário, respeita o estabelecido, pois o passageiro será integralmente indenizado pelos danos materiais, na eventualidade de perda ou extravio da bagagem. Frise-se, porém, ser o dispositivo relativo somente aos danos materiais. No que se refere aos danos morais, não é possível estabelecer sua prefixação (PEREIRA, 2009, p. 280-281).

Infelizmente, na prática, não se observa efetivo respeito à faculdade legal de o viajante declarar o valor da bagagem para efeitos de indenização. É raro o implemento, por parte das companhias aéreas, de informações concernentes à possibilidade do procedimento, oportunidade que resta ainda mais prejudicada com o advento do bilhete aéreo eletrônico (MORSELLO, 2007, p. 160). Não obstante, o Guia do Passageiro, disponibilizado pela Empresa Brasileira de Infraestrutura Aeroportuária (Infraero) informa o consumidor a respeito do direito de declaração do valor de bagagem (INFRAERO AEROPORTOS, 2019).

Sobre isso, entende Gonçalves (2017, p. 302) que, se a empresa não obtiver a declaração do valor da bagagem por parte do transportado, não haverá limitação da indenização, de modo que a empresa transferiu para si a obrigação de definir previamente o valor da bagagem, limitando a indenização.

A responsabilidade objetiva do transportador aéreo será afastada frente a determinadas situações anômalas, como estabelece o próprio Código Civil. Os artigos 734 e 737 admitem, expressamente, como excludente a "força maior". Sem adentrar na polêmica que envolve a distinção entre o caso fortuito e a força maior, a pesquisa doutrinária revela posicionamentos divergentes a respeito do primeiro.

Entre os estudiosos estrangeiros, Roberto de Ruggiero (2005, p. 464) comenta que o transportador pode exonerar-se da responsabilidade provando caso fortuito ou força maior. Compartilham do mesmo entendimento: Álvaro Villaça Azevedo (2004, p. 273), Flávio Tartuce (2018, p. 1.099), Fran Martins (2010, p. 234) e Arnaldo Rizzardo (2006, p. 796). A primeira excludente é negada por Araken de Assis (2005, p. 327-328) e Carlos Roberto Gonçalves (2003, p. 149), os quais interpretam restritivamente o artigo 734 do Código.

28 (Tradução Livre). No original, o artigo 1.681 do Código Civil italianoe prevê: "Sono nulle le clausole che limitano la responsabilitá del vettore per o sinistri che colpiscono il viaggiatore." (ITALIA, 2020).

29 A declaração de valor encontra previsão no artigo 22, alínea 2 da Convenção de Montreal e no artigo $234, \S 2^{\circ}$ do Código Brasileiro de Aeronáutica. 
Parece coerente o entendimento da primeira corrente, ao eximir a responsabilidade do transportador tanto no caso da força maior, como do caso fortuito. Destaca-se, contudo, a distinção entre "fortuito interno" (ligado à atividade do agente) e "fortuito externo" (força maior, ou act of God dos ingleses). Infere-se que somente o fortuito externo exclui a responsabilidade do transportador aéreo, não o isentando problemas mecânicos no veículo ou o tragamento de urubus em turbinas de aviões - fato corriqueiro no Brasil. Por outro lado, não há indenização se o retardamento na decolagem decorreu de fechamento do aeroporto em face de problemas meteorológicos (GUIMARÃES, 2007, p. 175-185).

Quanto aos riscos da atividade, Sergio Cavalieri Filho (2015, p. 432) explica dever ser a força maior apurada in concreto, visto que o avanço e a sofisticação do aparato tecnológico das medidas de segurança torna cada vez mais relativa a caracterização da irresistibilidade. Por exemplo, as intempéries da natureza podem ser previstas e possibilitam providências preventivas do dano.

É o caso do voo AF 447 da Air France, que caiu no Oceano Atlântico em 2009, matando 228 pessoas: a tempestade tropical estava prevista, mas o comandante optou por não alterar a rota, ao contrário dos outros aviões presentes naquela zona. E, como conclui o citado autor: "Se não pode impedir o mau tempo, pode prevê-lo e evitar a viagem, ou atenuar os seus efeitos hospedando os passageiros e dando-lhes tratamento adequado". Não se trata, pois, de responsabilizar o transportador aéreo pelo fenômeno natural, mas pela ineficácia do serviço (CAVALIERI FILHO, 2015, p. 434).

No que se refere à culpa de terceiro, o artigo 735 do Código Civil não a considera excludente de responsabilidade ${ }^{30}$. Assim, no caso de o acidente com o passageiro decorrer de culpa de terceiro, caberá ao transportador indenizar a vítima, tendo assegurado o respectivo direito de regresso contra o causador do dano. Na questão, o Código Civil é mais rígido com o transportador que o Código de Defesa do Consumidor, visto que o artigo $14, \S 3^{\circ}$, II do último documento elege a culpa de terceiro como excludente de responsabilidade.

Quanto ao transporte aéreo, responsabiliza-se a empresa aérea por acidente com morte de passageiros, mesmo que haja culpa de terceiros, inclusive dos agentes do Estado. A título de exemplo, cita-se o triste acidente da companhia aérea GOL, causado pelos pilotos americanos do Legacy 600, que se chocou contra a asa do Boing 737. A companhia aérea da GOL respondeu em face das vítimas, assegurado o direito de regresso contra os terceiros causadores do dano.

Frise-se que, para a responsabilidade do empresário, a atitude do terceiro deve-se apresentar como risco natural do transporte. Se há atitude violenta e inevitável (como roubo ou sequestro), os tribunais isentam o transportador do pagamento da indenização, ao tratar o caso como equivalente à força maior (AGUIAR JÚNIOR, 2003). Assim já se posicionou o Superior Tribunal de Justiça ${ }^{31}$. No entanto, se houver alteração unilateral do contrato de transporte aéreo

30 O legislador acompanhou, mais uma vez, o entendimento dos tribunais, consubstanciado na Súmula $n^{\circ} 187$ do Supremo Tribunal Federal.

31 STJ. Terceira Turma. Agravo Regimental no Recurso Especial n ${ }^{\circ}$ 2006/0035182-9 (BRASIL, 2013). 
para terrestre (cancelamento de voo), poderá haver o dever de indenizar os passageiros roubados ${ }^{32}$.

A culpa de terceiro reveste-se de importância, igualmente, quando estudada a indisciplina e a violência a bordo de aeronaves, fenômeno mundialmente crescente, denominado air rage syndrome, ou síndrome da fúria aérea. Nota-se que a inserção de pessoas em espaço fechado, com limitação de movimentos, o consumo de álcool cujos efeitos são potencializados em voo e o uso de medicação sedativa, ampliam a agressividade natural e a falta de tolerância às regras sociais. Denota-se o aumento do número de agressões físicas, ofensas verbais, ameaças de morte e atentado violento ao pudor contra a tripulação e os demais passageiros (MORSELLO, 2007, p. 293-298).

Considerando o aumento de incidentes decorrente de indisciplina, o Governo do Reino Unido tipificou a atitude como crime. Há notícias de companhias aéreas com adoção medidas preventivas e repressivas, como a advertência inserida pela Singapore Airlines, informando que atos indisciplinares culminarão com a aterrissagem prévia de aeronave, em escala não programada e ajuizamento de ação em face do infrator destinada à reparação de danos. A Scandinavian Airlines estabelece um sistema de sanções para passageiros que gritem, bebam de forma desmesurada e não atendam às ordens da tripulação, ou perturbem os demais passageiros. Caso haja propositura de ação em face do transportador aéreo, caber-lhe-á o ônus da prova do fato de terceiros, como excludente do dever de indenizar (MORSELLO, 2007, p. 293-298).

No Brasil, o transportador não dispõe do arbítrio de enjeitar passageiros, por ser qualificada a atitude como prática abusiva, nos termos do artigo 39, II do Código de Defesa do Consumidor. Nada obstante, ocorrendo atos indisciplinares, o infrator poderá ser impedido de embarcar ou ser retirado da aeronave. É o que preveem os artigos 738 e 739 do Código Civil, que descrevem expressamente duas exceções à obrigação de aceitar passageiro: os casos previstos nos regulamentos e a falta de higiene ou condições de saúde do interessado ${ }^{33}$. Se caracterizada a culpa concorrente, o montante da indenização pleiteada sofrerá redução equitativa, conforme o artigo 738, parágrafo único do Código Civil.

Ao contrário do estabelecido no Código Civil, o artigo $14, \S 3^{\circ}$ do Código de Defesa do Consumidor não considera a culpa concorrente como excludente de responsabilidade ou causa de redução da indenização. Sendo o contrato de transporte uma relação de consumo, a doutrina se divide em duas correntes. A primeira defende a desconsideração do artigo 738, parágrafo único, do Código Civil e, assim, o valor da indenização coincidirá com o valor integral do dano. Corrente

32 STJ. REsp 1728068/SP, Rel. Ministro Marco Aurélio Bellizze (BRASIL, 2018).

33 A primeira reserva estende-se às cláusulas gerais de negócio estabelecidas unilateralmente pelo transportador, desde que não sejam discriminatórias. Assim, é lícito ao transportador impedir que animais tenham acesso ao veículo, mas o deficiente visual poderá ser acompanhado do cão-guia devidamente treinado (COELHO, 2010, p. 412-413). No caso dos transportes aéreos, os atentados terroristas e os sequestros de aeronaves impõem às companhias inúmeras disposições visando à segurança do voo (VENOSA, 2012, p. 345). A segunda exceção do artigo 738 autoriza o transportador a não aceitar a condução de passageiros que exalam mau cheiro extremo (GONÇALVES, 2012, p. 497), e que estejam com moléstias contagiosas, devendo no segundo caso deslocá-los em veículos especiais ou compartimentos separados (se existirem) (RIZZARDO, 2006, p. 797). Ademais, é razoável admitir a recusa de transporte de presidiários, pelo dever de segurança e de conforto perante os demais passageiros (LOTUFO, 2002, p. 205-214). Outras situações são admitidas como a recusa de passageiro que não esteja adequadamente vestido, que esteja embriagado ou drogado, que porte arma branca ou de fogo, que traga consigo cobra venenosa (GONÇALVES, 2003 , p. 148). Não há, neste caso, indicação no Código Civil se o valor da passagem deverá ser restituído, mas parece que deva fazê-lo, sob pena de locupletamento indevido. A restituição, desta maneira, deverá ser proporcional ao restante da viagem, podendo, por analogia, aplicar a multa compensatória do art. 740, $\$ 3^{\circ}$ (FALAVIGNA, 2008, p.365-370.) 
contrária alega que a culpa concorrente da vítima constitui causa de redução do montante da indenização pleiteada, em proporção ao grau de culpa comprovada nos autos (GONÇALVES, 2003, p. 148). Coerente o primeiro posicionamento que respeita a defesa constitucionalmente prevista do consumidor.

A culpa exclusiva da vítima é excludente de responsabilidade objetiva do transportador, visto que o legislador não adotou a teoria do risco integral. A ausência de previsão no Código Civil não faz falta (DIAS, 2012, p. 212), mas se a relação é de consumo, o transportador poderá alegá-la com base no artigo $14, \S 3^{\circ}$, II do Código de Defesa do Consumidor.

Se a relação não é de consumo, poder-se-á fundamentar a presença da excludente no artigo 21 da Convenção de Montreal e, cabe ao transportador o ônus da prova da culpa exclusiva da vítima (MORSELLO, 2007, p. 291). É o entendimento de Carlos Roberto Gonçalves (2003, p. 149) e, na doutrina estrangeira, Philippe Le Tourneau et al. (2008, p. 4477). ${ }^{34}$

Expressamente, o artigo 256, $\S 1^{\circ}$ do Código Brasileiro de Aeronáutica prevê que a pretensão à reparação desaparece se a morte ou a lesão do passageiro resultar, exclusivamente, do seu estado de saúde ou o acidente decorrer de culpa exclusiva. E, de fato, se o passageiro não atende aos avisos de fechar o cinto de segurança, decerto infringe os deveres impostos pelo art. 738 do Código Civil, e por isso, advinda alguma lesão, como em virtude de turbulências no curso da viagem, nenhuma indenização será devida (ASSIS, 2005, p. 328).

Assim, no caso de culpa da exclusiva da vítima, "não se deve levar o princípio da responsabilidade objetiva a extremos que cheguem à injustiça; no caso o dano não é indenizável" (MONTEIRO; MALUF; SILVA, 2009, p. 348-349), apesar da ausência de previsão expressa no Código Civil (PEREIRA, 2009, p. 281).

A obrigação do transportador em observar os horários e os itinerários, expressa ou tacitamente convencionados, encontra respaldo no artigo 737 do Código Civil. Como o viajante se baseia neles para organizar os compromissos (DINIZ, 2006, p. 443), o transportador deve observálos (MIRANDA, 2012, p. 126), sob pena de responder por perdas e danos. A responsabilidade pelo atraso e pela mudança de itinerário contratado é crucial em transporte aéreo, no qual são múltiplos os problemas motivadores da alteração pactuada, com ou sem culpa do prestador de serviços (VENOSA, 2012, p. 345).

A respeito do atraso, duas observações são necessárias. Inicialmente, se por qualquer circunstância o horário não puder ser cumprido rigorosamente, para o passageiro exigir a indenização deverá comprovar o prejuízo (GOMES, 2009, p. 381). A segunda ressalva é que, no transporte aéreo, a lei tolera certo atraso, mas ultrapassado respectivo período, o empresário deverá providenciar o embarque dos passageiros em voo que ofereça serviço equivalente ou restituir de imediato o valor da passagem (COELHO, 2010, p. 414). Na hipótese de suspensão do voo, correm por conta do transportador as despesas com alimentação e hospedagem, acrescidas ao prejuízo da

34 Na França, André Tunc esclarece que, em 1924, a lei impôs uma responsabilidade severa e a culpa da vítima era a única causa de exclusão ou diminuição da responsabilidade do transportador aéreo (TUNC, 1989, p. 71, tradução nossa). No original: "En 1924, une loi imposait une responsabilité plus sévère encore à l'exploitant d'un avion pour les dommages causés aux personnes ou aux propriétés au sol. La faute de la victime était la seule cause possible d'exemption ou de diminuition de la responsabilité de l'exploitant" (TUNC, 1989, p. 71). 
indenização que couber, inclusive por danos morais (TARTUCE, 2007, p. 523).

Quanto ao itinerário, caberá ao transportador respeitá-lo, de modo a evitar o aumento das distâncias, bem como a passagem por lugares perigosos. Alterado o percurso, o viajante poderá exigir a resolução do contrato e o ressarcimento dos danos. Se o que ocorreu determinou o aumento do preço, o empresário não terá direito de cobrá-lo do passageiro. Quanto à supressão de paradas anteriormente previstas, se não observado caso fortuito ou força maior, o viajante poderá exigir o ressarcimento dos danos (MIRANDA, 2012, p. 127).

O artigo 740 do Código Civil prevê inúmeras situações em que o passageiro desiste da viagem. A regra geral é pela admissão da "rescisão" (ou resilição unilateral), desde que em tempo suficiente para o transportador renegociar com terceiro, situação que permitirá a devolução do valor da passagem. É possível afirmar, dessa maneira, que o arrependimento tempestivo é aceito e o valor da passagem restituído. Quando intempestivo, isto é, o passageiro simplesmente não comparece no horário e local estabelecido para o embarque, tão somente terá direito ao reembolso do valor pago se provar que outra pessoa foi conduzida em seu lugar.

Ademais, o arrependimento pode acontecer no transcorrer da viagem, situação em que o viajante terá direito à restituição do montante correspondente ao trecho não utilizado, se conseguir provar que o seu lugar foi ocupado por outra pessoa. Em todos os casos acima expostos, o transportador poderá reter cinco por cento do valor pago, a título de multa compensatória.

Se a relação se configurar como de consumo, aplicar-se-á o artigo $6^{\circ}$, VIII do Código de Defesa do Consumidor. Referido entendimento possibilita a inversão do ônus da prova. Destarte, a prova de que outra pessoa tenha sido transportada em seu lugar não competirá ao passageiro, mas ao transportador caberá a demonstração do prejuízo. Mais uma vez, confrontam-se "aparentemente" o disposto no Código Civil e no Código de Defesa do Consumidor.

Não há, ainda, antinomia entre a multa de cinco por cento da importância a ser restituída ao passageiro, assegurada ao transportador no artigo $740, \S 3^{\circ}$ do Código Civil, e a multa de dois por cento, fixada no artigo $52, \S 1^{\circ}$ do Código de Defesa do Consumidor. Isto porque, enquanto a primeira reveste-se de caráter compensatório, a multa de dois por cento é empregada para hipóteses de mora do consumidor (LOTUFO, 2002, p. 205-214).

Como a passagem aérea é pessoal e intransferível, sugere-se que o passageiro verifique as regras do contrato antes do cancelamento, pois a mudança poderá gerar custos adicionais (em caso de remarcação) ou a empresa poderá reter parte do valor pago (reembolso).

Relevante, ainda, é observar o horário de apresentação estipulado pela companhia aérea, que pode ser de pelo menos uma hora de antecedência para voos nacionais e, de duas horas para voos internacionais, conforme estabelecido pela companhia aérea.

No estudo de transporte aéreo, as questões de "rescisão" são de extrema relevância, visto que o artigo 740 do Código Civil guarda relação direta com os passageiros de aeronaves que, apesar de portarem bilhete e reserva, deixam de comparecer no aeroporto para o embarque na data e na hora previstas (no show). Por outro lado, os transportadores aéreos costumam reservar número maior de passageiros do que comporta a aeronave (overseating ou overbooking) (MONTEIRO; 
MALUF; SILVA, 2009, p. 350).

Como regra geral, nos casos de atraso, cancelamento de voo e preterição de embarque (embarque não realizado por segurança operacional, troca de aeronave, overbooking etc.), o usuário será acomodado em outro voo. Terá direito à assistência material, como comunicação, alimentação e acomodação. A assistência será gradual, conforme o tempo de espera.

Nos termos do artigo 741 do Código Civil, em qualquer hipótese, ainda que por caso fortuito, se a viagem for interrompida, o transportador fica obrigado a concluir o transporte convencionado em outro veículo da mesma categoria, à própria custa. Se houver concordância do passageiro, o transporte complementar poderá ser efetuado por modalidade diferente, mas sempre custeado pelo transportador (THEODORO JÚNIOR, 2003, p. 11-26).

\section{CONSIDERAÇÕES FINAIS}

Considerada a relevância do transporte para a sociedade atual, o Código Civil de 2002 inovou ao inserir disposições gerais e especiais a respeito do contrato de transporte de pessoas e de coisas. Para o contrato de transporte de pessoas e bagagens, por via aérea, verificou-se que é exigida a aplicação conjunta do Código Civil, do Código de Defesa do Consumidor (quando a relação for caracterizada como de consumo) e da legislação específica, como a Convenção de Montreal e o Código Brasileiro de Aeronáutica.

A aplicação conjunta da legislação exigirá muitas vezes do intérprete a utilização dos critérios para a solução das antinomias. Ao contrário do entendimento majoritário da doutrina, o Supremo Tribunal Federal entendeu que prevalecem as regras da Convenção de Montreal e demais acordos internacionais, no sentido de limitar o valor da indenização para a hipótese de extravio de bagagem em voos internacionais. A interpretação favoreceu as transportadoras aéreas em detrimento dos interesses consumeristas.

Apesar de tal posição, nos contratos de transporte de passageiros e bagagens por via aérea, é importante não olvidar da força unificadora da Constituição Federal e da nova principiologia contratual, que é semelhante no Código Civil e no Código de Defesa do Consumidor. Garantir a função social do contrato, privilegiar a boa-fé objetiva e assegurar a dignidade da pessoa humana, bem como a justiça nas relações devem ser objetivos fundamentais para o aplicador do direito.

\section{REFERÊNCIAS}

AGUIAR JÚNIOR, Ruy Rosado de. Contrato de Transporte de Pessoas e o Novo Código Civil. In: PEREIRA, Antônio Celso Alves; MELLO, Carlos Renato Duvivier de Albuquerque (org.). Estudos em homenagem a Carlos Alberto Menezes Direito. Rio de Janeiro: Renovar, 2003. p. 617-633.

ALBALADEJO, Manuel. Derecho civil. 2. ed. Barcelona: Bosch, 1975. v. 2. 
ASSIS, Araken de. Contratos nominados. São Paulo: Revista dos Tribunais, 2005. v. 2.

AZEVEDO, Álvaro Villaça. Teoria geral das obrigações: responsabilidade civil. 10. ed. São Paulo: Atlas, 2004.

BENJAMIN, Antônio Herman de Vasconcellos e. O transporte aéreo e o Código de Defesa do Consumidor. Revista de direito do consumidor, São Paulo, v. 26, p. 33-44, abr./jun. 1998.

BITTAR, Carlos Alberto. Contratos comerciais. 5. ed. Rio de Janeiro: Forense Universitária, 2008.

BRASIL. Lei n. 10.406, de 10 de janeiro de 2002. Institui o Código Civil. Diário Oficial da União: Seção 1, Brasília, DF, n. 8, p. 1, 11 jan. 2002. Disponível em: http://www.planalto.gov.br/ ccivil_03/leis/2002/L10406compilada.htm. Acesso em: 12 out. 2020.

BRASIL. Supremo Tribunal de Justiça. Agravo Regimental no Recurso Especial n.

823101 RJ 2006/0035182-9. Agrovo regimental no recurso especial. Responsabilidade civil. Transporte de passageiro em coletivo. Assalto. Passageiro atingido por disparo de arma de fogo. Responsabilidade do transportador afastada. Precedentes. Relator: Ministro Ricardo Villas Bôas Cueva. Órgão Julgador T3, 29 de junho de 2013. Disponível em: https://stj.jusbrasil.com.br/ jurisprudencia/23841585/agravo-regimental-no-recurso-especial-agrg-no-resp-823101-rj-20060035182-9-stj/inteiro-teor-23841586. Acesso em: 19 jun. 2020.

BRASIL. Supremo Tribunal de Justiça. Recurso Especial - REsp 1728068/SP. Recurso especial. Responsabilidade Civil. Transporte aéreo que seguiu via terrestre (Ônibus) em virtude de cancelamento do vôo. Órgão Julgador T3. Recorrente: Passaredo Transportes Aéreos S.A. Recorrido: João Carlos Pereira. Relator: Ministro Marco Aurélio Bellizze. 5 de junho de 2018. Disponível em: https://stj.jusbrasil.com.br/jurisprudencia/595911051/recurso-especial-resp1728068-sp-2017-0312873-5/inteiro-teor-595911070. Acesso em: 23 out. 2020.

BRASIL. Supremo Tribunal de Justiça. Recurso Especial- Resp. 1842066 RS 2019/02998044. Recurso Manejado sob a égide do NCPC. Ação indenizadora transporte aéreo internacional. Recorrente: Societe Air France. Recorrido: Humberto Neubauer Grala. Recorrido: Rosmari Filomena Franzoi Grala. Relator: Ministro Moura Ribeiro, 9 de junho de 2020. Disponível em: https://stj.jusbrasil.com.br/jurisprudencia/860882831/recurso-especial-resp-1842066rs-2019-0299804-4/inteiro-teor-860882840?ref=juris-tabs. Acesso em: 22 out. 2020.

BRASIL. Supremo Tribunal Federal. Recurso Extraordinário 636.331. Recurso extraordinário com repercussão geral. Extravio de bagagem. Dano material. Recorrente: Société Air France. Recorrido: Sylvia Regina de Moraes Rosolem. Relator: Ministro Gilmar Mendes, 25 de maio de 2017. Disponível em: http://www.stf.jus.br/portal/jurisprudencia/menuSumarioTese. asp?tipo=TRG\&tese $=4845$. Acesso em: 23 out. 2020 .

BUNDESMINISTERIUM DER JUSTIZ UND FÜR VERBRAUCHERSCHUTZ. Bürgerliches Gesetzbuch (BGB) § 242 Leistung nach Treu und Glauben. Disponível em: https://www. gesetze-im-internet.de/bgb/_242.html. Acesso em: 23 out. 2020.

CACHARD, Olivier. Le transport international aérien de passagers. 2015. Disponível em: https://books.google.com.br. Acesso em: 27 out. 2020.

CAVALIERI FILHO, Sergio. Programa de responsabilidade civil. 12. ed. São Paulo: Atlas, 2015. 
COELHO, Fábio Ulhoa. Curso de direito civil: contratos. 4. ed. São Paulo: Saraiva, 2010. v. 3.

CONSELHO DA JUSTIÇA FEDERAL. Enunciado 171. Brasília: CJF, [2002?a]. Disponível em: https://www.cjf.jus.br/enunciados/enunciado/305. Acesso em: 22 out. 2020.

CONSELHO DA JUSTIÇA FEDERAL. Enunciado 369. Brasília: CJF, [2002?b]. Disponível em: https://www.cjf.jus.br/enunciados/enunciado/493. Acesso em: 22 out. 2020.

CONSELHO DA JUSTIÇA FEDERAL. Enunciado 559. Brasília: CJF, [2006?]. Disponível em: https://www.cjf.jus.br/enunciados/enunciado/630. Acesso em: 22 out. 2020.

DIAS, José de Aguiar. Da responsabilidade civil. 12. ed. Rio de Janeiro: Lumen Juris, 2012.

DINIZ, Maria Helena. Tratado teórico e prático dos contratos. 6. ed. São Paulo: Saraiva, 2006. v. 4.

FALAVIGNA, Maria Clara. Contrato de transporte. In: HIRONAKA, Giselda Maria Fernandes Novaes Hironaka (org.). Direito dos contratos. São Paulo: Revista dos Tribunais, 2008. v. 3.

FERREIRA, Waldemar Martins. Instituições de direito comercial. São Paulo, Rio de Janeiro: Freitas Bastos, 1944. v. 2.

GILISSEN, John. Introdução histórica ao direito. 3. ed. Lisboa: Fundação Caloustre Gulbenkian, 2001.

GODOY, Cláudio Luiz Bueno de. In: PELUSO, Cezar (coord.). Código civil comentado. 2. ed. Barueri: Manole, 2008.

GOMES, Orlando. Contratos. 26. ed. Rio de Janeiro: Forense, 2009.

GONÇALVES, Carlos Roberto. A responsabilidade civil decorrente do transporte. In: DELGADO, Mário Luiz; ALVES, Jones Figueirêdo (coord.). Os grandes temas de direito civil nos 15 anos do código civil: homenagem especial ao professor Álvaro Villaça Azevedo. São Paulo: IASP, 2017. p. 292-305.

GONÇALVES, Carlos Roberto. Comentário ao código civil: parte especial. São Paulo: Saraiva, 2003. v. 11.

GONÇALVES, Carlos Roberto. Direito civil brasileiro: contratos e atos unilaterais. 9. ed. São Paulo: Saraiva, 2012. v. 3.

GRAU, Eros Roberto. Transporte aéreo de passageiros; dano moral causado a passageiro: prevalência do Código Brasileiro de Aeronáutica sobre o Código de Defesa do Consumidor. In: WALD, Arnoldo (org.). Direito empresarial: contratos mercantis. São Paulo: Revista dos Tribunais, 2011. v. 4.

GUIMARÃES, Paulo Jorge Scartezzini. Dos contratos de hospedagem, de transporte de passageiros e de turismo. São Paulo: Saraiva, 2007.

INFRAERO AEROPORTOS. Guia do passageiro. Disponível em: https:/www4.infraero.gov. br/aeroportos/aeroporto-de-sao-paulo-congonhas-deputado-freitas-nobre/sobre-o-aeroporto/guia- 
do-passageiro. Acesso em: 10 out. 2019.

ITALIA. [R.D. 16 marzo 1942, n. 262]. Codice Civile 2020. Padova: Brocardi. IT, [2020]. Articolo 1681. Disponível em: https:/www.brocardi.it/codice-civile/libro-quarto/titolo-iii/capoviii/sezione-ii/art1681.html\#: :text=7423\%2F1999-,L'art.,vettore20nell' esecuzione\%20del\%20 trasporto. Acesso em: 23 out. 2020.

ITALIA. Codice civile. Libro IV, Titolo III, Capo VIII. Altalex, Milano, 2 ago. 2018. Disponível em: https://www.altalex.com/documents/news/2013/04/11/del-trasporto. Acesso em: 23 out.2020. LE TOURNEAU, Philippe; BLOCH, Cyril; GIUDICELLI, André; KRAJESKI, Didier; GUETTIER, Christophe; JULIEN, Jérôme; STOFFEL-MUNCK, Philippe. Droit de la responsabilité et des contrats. 7. ed. Paris: Dalloz, 2008.

LOTUFO, Renan. O contrato de transporte de pessoas no novo código Civil. Revista de direito do consumidor, São Paulo, ano 11, v. 43, p. 205-214, jul./set. 2002.

MARQUES, Cláudia Lima. Contratos no código de defesa do consumidor: o novo regime das relações contratuais. 5. ed. São Paulo: Revista dos Tribunais, 2005.

MARTINS, Fran. Contratos e obrigações comerciais. 16. ed. Rio de Janeiro: Forense, 2010.

MARTINS-COSTA, Judith. A boa-fé no direito privado: critérios para a sua aplicação. 2. ed. São Paulo: Saraiva Educação, 2018.

MELO, Marco Aurélio Bezerra de. A responsabilidade civil no transporte de cortesia (carona). Genjurídico, São Paulo, 14 abr. 2016. Disponível em: http://genjuridico.com.br/2016/04/14/aresponsabilidade-civil-no-transporte-de-cortesia-carona. Acesso em: 27 out. 2020.

MIRAGEM, Bruno. Curso de direito do consumidor. 7. ed. rev., atual. e ampl. São Paulo: Revista dos Tribunais, 2018.

MIRANDA, Francisco Cavalcanti Pontes de. Tratado de direito privado. São Paulo: Revista dos Tribunais, 2012.

MONTEIRO, Washington de Barros; MALUF, Carlos Alberto Dabus; SILVA, Regina Beatriz Tavares da. Curso de direito civil: direito das obrigações: 2 parte: dos contratos em geral, das várias espécies de contratos, dos atos unilaterais, da responsabilidade civil. 36. ed. São Paulo: Saraiva, 2009. v. 5.

MORSELLO, Marco Fábio. A boa-fé objetiva e os direitos dos passageiros no transporte aéreo. Novos paradigmas. In: ROSENVALD, Nelson; DRESCH, Rafael de Freitas Valle; WESENDONCK, Tula. (coord.). Responsabilidade civil: novos riscos. Indaiatuba: Foco, 2019. p. 177-198.

MORSELLO, Marco Fábio. O contrato de transporte caracterizado como tipo geral. Conceito. Natureza jurídica. Características. In: JABUR, Gilberto Haddad; PEREIRA JÚNIOR, Antonio Jorge (coord.). Direito dos contratos. São Paulo: Quartier Latin, 2006. p. 386-403.

MORSELLO, Marco Fábio. O sistema de Defesa do Consumidor e sua interface com o contrato de transporte aéreo. In: GUERRA, Alexandre Dartanhan de Mello; MALFATTI, Alexandre David (coord.). Reflexões de magistrados paulistas nos 25 anos do Código de Defesa do Consumidor. São Paulo: Escola Paulista da Magistratura, 2015. p. 111-138.

MORSELLO, Marco Fábio. Responsabilidade civil no transporte aéreo. São Paulo: Atlas, 
2007.

NADER, Paulo. Curso de direito civil: contratos. 5. ed. Rio de Janeiro: Forense, 2010. v. 3.

PACHECO, José da Silva. Comentários ao código brasileiro de aeronáutica: Lei $\mathrm{n}^{0} 7.565$, de 19 de dezembro de 1986. Rio de Janeiro: Forense, 1990.

PEREIRA, Caio Mário da Silva. Instituições de direito civil. 13. ed. Rio de Janeiro: Forense, 2009. v. 3.

RÉPUBLIQUE FRANÇAISE. Code civil. Paris: Légifrance, 1 sept 2020. Disponível em: https://www.legifrance.gouv.fr/download/pdf/legiOrKali?id=LEGITEXT000006070721. pdf\&size $=1,3 \% 20$ Mo\&pathToFile=/LEGI/TEXT/00/00/06/07/07/21/LEGITEXT000006070721/ LEGITEXT000006070721.pdf\&title=Code\%20civil. Acesso em: 23 out. 2020.

RIPERT, Georges. Droit maritime. 3. ed. Paris: Arthur Rousseau, 1929. v. 2.

RIZZARDO, Arnaldo Contratos. 6. ed. Rio de Janeiro: Forense, 2006.

ROPPO, Enzo. O contrato. Coimbra: Almedina, 1988.

RUGGIERO, Roberto de. Instituições de direito civil. 2. ed. Campinas, São Paulo: Bookseller, 2005. v. 3.

SALOMÃO, Luis Felipe. Direito privado: teoria e prática. 3. ed. São Paulo: Saraiva, 2016.

SANSEVERINO, Paulo de Tarso Vieira. A boa-fé objetiva no direito brasileiro. In: SALOMÃO, Luis Felipe; TARTUCE, Flávio. (coord.). Direito civil: diálogo entre a doutrina e a jurisprudência. São Paulo: Atlas, 2018. p. 184.

SÃO PAULO. Tribunal de Justiça de São Paulo. Apelação Cível 1023703-70.2019.8.26.0100. Transporte de passageiros, matéria que não se insere na competência das $25^{\mathrm{a}}$ a $36^{\mathrm{a}}$ Câmaras da Seção de Direito Privado. Apelante: TAM - Linhas Aéreas S.A. Apelado: Paulo Octtávio Moura de Almeirda Calhão. Órgão Julgador: $38^{\mathrm{a}}$ Câmara de Direito Privado. Foro Central Cível - 32a Vara Cível. Relator: Flávio Cunha da Silva, 2 de outubro de 2020. Disponível em: https:// tj-sp.jusbrasil.com.br/jurisprudencia/898655066/apelacao-civel-ac-10237037020198260100sp-1023703-7020198260100/inteiro-teor-898655126?ref=juris-tabs. Acesso em: 23 out. 2020.

SÃO PAULO. Tribunal de Justiça de São Paulo. Apelação Cível 9119532-78.2001.8.26.0000 SP 9119532-78.2001.8.26.0000. Acidente de veículo ação de indenização por danos materiais e morais transporte gratuito prestado por uma das corrés, em que o filho dos autores veio a falecer. Apelantes: Antônio Miguel Estevão; Angelina Amâncio Estevão. Apelados: Papaléguas Encomendas e Cargas Ltda. Relator: Jayme Queiroz Lopes, 19 de setembro de 2019. Disponível em: https://j-sp.jusbrasil.com.br/jurisprudencia/911831117/apelacao-civel-ac91195327820018260000-sp-9119532-7820018260000?ref=serp. Acesso em: 23 out. 2020.

SCHREIBER, Anderson. A proibição do comportamento contraditório: tutela da confiança e venire contra factum proprium. 4. ed. São Paulo: Atlas, 2016.

SCHREIBER, Anderson; TARTUCE, Flavio; SIMÃO, José Fernando; MELO; Marco Aurélio Bezerra de; DELGADO, Mario Luiz. Código Civil Comentado: doutrina e jurisprudência. Rio 
de Janeiro: Forense, 2019.

SIMÃO, José Fernando. Quem tem medo de dar carona? Mobilidade urbana e o transporte gratuito. Jornal Carta Forense, São Paulo, 1 set. 2014. Disponível em: http://www.cartaforense. com.br/conteudo/colunas/quem-tem-medo-de-dar-carona-mobilidade-urbana-e-o-transportegratuito/14373. Acesso em: 27 out. 2020.

STOCO, Rui. Tratado de responsabilidade civil: doutrina e jurisprudência. 8. ed. São Paulo: Revista dos Tribunais, 2011.

TARTUCE, Flávio. Direito civil: teoria geral dos contratos e contratos em espécie. 2. ed. São Paulo: Método, 2007. v. 3.

TARTUCE, Flávio. Direito civil: teoria geral dos contratos e contratos em espécie. 14 ed. Rio de Janeiro: Forense, 2019. v. 3.

TARTUCE, Flávio. Manual de responsabilidade civil: volume único. Rio de Janeiro: Forense; São Paulo: Método, 2018.

TEPEDINO, Gustavo; KONDER, Carlos Nelson; BANDEIRA, Paula Greco. Fundamentos do Direito Civil: contratos. Rio de Janeiro: Forense, 2020.

THEODORO JÚNIOR, Humberto. Do transporte de pessoas no novo Código Civil. Revista dos Tribunais, v. 807, p. 11, jan. 2003.

TOMASEVICIUS FILHO, Eduardo. O princípio da boa-fé objetiva no direito civil. São Paulo: Almedina, 2020.

TUNC, André. La responsabilité civile. 2. ed. Paris: Economica, 1989.

VENOSA, Sílvio de Salvo. Direito civil: contratos em espécie. 12. ed. São Paulo: Atlas, 2012. v. 3.

Como citar: PAIANO, Daniela Braga. FURLAN, Alessandra Cristina. Aspectos polêmicos do contrato de transporte aéreo de passageiros e bagagens Scientia Iuris, Londrina, v. 24, n. 3, p. 119-142, nov. 2020. DOI: 10.5433/2178-8189.2020v24n3p119. ISSN: 2178-8189.

Recebido em: 27/02/2020

Aprovado em: 30/10/2020 